\title{
HETEROGENEOUS FENTON-LIKE DECOLORIZATION OF PROCION RED MX-5B WITH IRON- ALGINATE GEL BEADS AS AN EFFECTIVE CATALYST
}

\author{
Memduha ERGÜT, Ayla ÖZER
}

\begin{abstract}
In the present study, iron-alginate gel beads (Fe-Alg gel beads) were synthesized by the entrapment method and subsequently, the prepared gel beads were characterized by FTIR, SEM, and EDX analysis methods. The characterization studies showed that Fe-Alg gel beads were of spherical morphology and iron was successfully entrapped in alginate. Subsequently, the synthesized Fe-Alg gel beads were used as a heterogeneous catalyst for the decolorization of a hazardous azo-dyestuff, Procion Red MX-5B (PR MX-5B), with Fenton-like decolorization. The effects of process parameters such as initial pH, $\mathrm{H}_{2} \mathrm{O}_{2}$ concentration, initial dye concentration and catalyst concentration on Fenton-like decolorization were investigated. For Fenton-like decolorization of PR MX-5B, the optimum process parameters were determined to be pH: $3.0,20 \mathrm{m \mu}$ of $\mathrm{H}_{2} \mathrm{O}_{2}$ concentration, $50 \mathrm{mg} / \mathrm{L}$ of initial dye concentration, and $5.0 \mathrm{~g} / \mathrm{L}$ of catalyst concentration, respectively. The reaction kinetics was well fitted to second order reaction kinetics. As a result, the synthesized gel beads have a high color removal efficiency for PR MX-5B dye from an aqueous solution.
\end{abstract}

Keywords: decolorization; gel beads; heterogeneous Fenton-like catalyst; iron-alginate; Procion Red MX-5B

\section{INTRODUCTION}

Nowadays, dyes are utilized in approximately all industrial sectors; therefore, dye-laden wastewaters contaminate natural waters and reduce water's appreciate in use [1]. For this reason; several physicals, chemical and biological treatment methods such as adsorption, ion-exchange, photocatalysis, membrane separation, coagulation, electrocoagulation, and wet air oxidation have been tested to remove dye effluents and many of these techniques have their advantages and disadvantages. These advanced processes are not always efficient enough since the removal of dyes are difficult due to their water solubility and high molecular strength. Moreover, they have suffered from the generation of toxic chemical sludges as a result of the transfer of pollution from the wastewater to the solid phase, high operational costs of some and their limited applicability $[2,3]$.

Recently, advanced oxidation processes (AOPs) such as Fenton, photo-Fenton processes, electro-Fenton, ozonation, electrochemical oxidation, photolysis with $\mathrm{H}_{2} \mathrm{O}_{2}$ and $\mathrm{O}_{3}$, and $\mathrm{UV} / \mathrm{H}_{2} \mathrm{O}_{2}$ processes have attracted considerable attention as they are alternative methods without sludge formation for the treatment of a wide variety of organic contaminants in wastewaters. Their degradation mechanism mainly depends on the generation and the oxidative behavior of hydroxyl radicals [4]. The complicated organic molecules could be either oxidized to smaller organics or entirely mineralized to carbon dioxide $\left(\mathrm{CO}_{2}\right)$ and water $\left(\mathrm{H}_{2} \mathrm{O}\right)$ by $\mathrm{OH} \bullet$ radicals under treatment by AOPs [5].

The Fenton-like process which is the most hopeful method among the AOPs is a strong source of hydroxyl radicals from $\mathrm{H}_{2} \mathrm{O}_{2}$ in the presence of iron cations at an acidic medium. Conventional homogeneous Fenton's oxidation includes the implementation of ferrous or ferric salts and hydrogen peroxide to generate hydroxyl radicals. The main principle of oxidation was presented in Eqs. (1)-(2):
$\mathrm{Fe}^{2+}+\mathrm{H}_{2} \mathrm{O}_{2} \rightarrow \mathrm{OH} \bullet+\mathrm{OH}^{-}+\mathrm{Fe}^{3+}$
$\mathrm{Fe}^{3+}+\mathrm{H}_{2} \mathrm{O}_{2} \rightarrow \mathrm{Fe}^{2+}+\mathrm{H}^{+}+\mathrm{HO}_{2} \bullet$

The traditional homogeneous Fenton process is a simple process owing to operating at room temperature and atmospheric pressure. Additionally, it is quite effective when the wastewater contains suspended solids at high levels due to limited photon penetration. However, the important drawbacks of this process are narrow working $\mathrm{pH}$ range that is reported and that generally results in higher degradation yield at around $\mathrm{pH} 3.0$, the trouble of separation and recovery of the homogeneous catalyst and the formation of the large volume of iron sludge.

Therefore, to get rid of this problem, the usage of heterogeneous Fenton catalysts has been improved, such as iron-containing metal oxides, iron-containing bimetallic nanoparticles, iron-bearing porous materials such as clays, resins, zeolites, mesoporous substances, and iron species supported by neutral organic polymers (i.e., sodium alginate, sodium carboxymethyl cellulose) and inorganic materials [6 $-8]$.

Sodium alginate (SA) is one of the extensively studied natural polysaccharides to produce stable gels owing to its reaction ability with many cations such as $\mathrm{Fe}^{3+}, \mathrm{Ca}^{2+}$, and $\mathrm{Ba}^{2+}$ [9]. In the present study, iron was entrapped in sodium alginate, which is a biopolymer matrix, to prevent producing sludge at the end of the reaction. The entrapment method within alginate beads is one of the most extensive, effective, simple and inexpensive techniques for the entrapment of surfactants, activated carbon, and especially metal hydroxides (i.e., $\mathrm{Fe}^{3+}$ and $\mathrm{Ni}^{2+}$ ) for wastewater treatment. The benefits of entrapment within alginate beads are non-toxicity and biodegradability as well as their porosity facilitates interaction with the entrapped material diffusion of solutes into beads. Moreover, these gels can be separated from the 
reaction medium by a simple filtration owing to their waterinsoluble properties [10].

The objective of the presented study was synthesis and characterization of Fe-alginate gel beads and investigation of the applicability of them as a heterogeneous catalyst for the Fenton-like decolorization of a textile azo-dye, Procion Red MX-5B, in a batch system. For this purpose, the main process parameters such as the concentration of $\mathrm{H}_{2} \mathrm{O}_{2}$, initial $\mathrm{pH}$ of the solution, initial dye concentration and catalyst (Fe-Alg gel beads) concentration on Fenton-like decolorization were investigated.

\section{MATERIAL AND METHODS}

\subsection{Materials and Preparing of the Solutions}

The monoazo dye Procion Red MX-5B (PR MX-5B), also called the Reactive Red 2, was supplied by SigmaAldrich. PR MX-5B was of commercial purity (Type: Anionic, $M_{\mathrm{w}}=615.33 \mathrm{~g} / \mathrm{mol}, \lambda_{\max }=538 \mathrm{~nm}$ ). PR MX-5B has an azo double bond as a member of the chromophoric group. The chromophoric groups absorb light and affect visibility in water bodies [11]. PR MX-5B has an elemental composition of $\mathrm{C}_{19} \mathrm{H}_{10} \mathrm{Cl}_{2} \mathrm{~N}_{6} \mathrm{Na}_{2} \mathrm{O}_{7} \mathrm{~S}_{2}$, and its chemical structure is presented in Fig. 1.

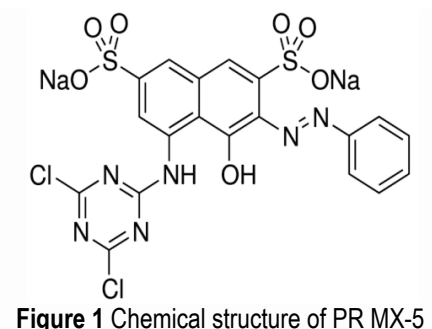

$\mathrm{FeCl}_{3}, \mathrm{BaCl}_{2} \cdot 2 \mathrm{H}_{2} \mathrm{O}$, and $\mathrm{H}_{2} \mathrm{O}_{2}(30 \%)$ were provided from Merck. Sodium alginate $\left(\mathrm{C}_{6} \mathrm{H}_{9} \mathrm{NaO}_{7}\right)$ was purchased from Sigma Aldrich.

The stock PR MX-5B solution of $1000 \mathrm{mg} / \mathrm{L}$ was prepared by dissolving $1 \mathrm{~g}$ of dye in $1 \mathrm{~L}$ of deionized water; then the desired PR MX-5B concentrations were prepared by proper dilutions from stock dye solution. $10 \mathrm{mM}, 20 \mathrm{mM}$ and $30 \mathrm{mM}$ of $\mathrm{H}_{2} \mathrm{O}_{2}$ solutions were prepared by dilution from the $50 \mathrm{mM}$ of stock $\mathrm{H}_{2} \mathrm{O}_{2}$ solution which was prepared from the $30.0 \% \mathrm{H}_{2} \mathrm{O}_{2}$ solution $(9.73 \mathrm{M})$. The solution of sodium alginate $2.0 \%(\mathrm{w} / \mathrm{v})$ was prepared by dissolving the required weight of sodium alginate in $100 \mathrm{~mL}$ deionized water. 0.15 $\mathrm{M} \mathrm{Ba}^{2+}$ and $0.05 \mathrm{M} \mathrm{Fe}^{3+}$ solutions were prepared by dissolving an accurate weight of $\mathrm{BaCl}_{2} \cdot 2 \mathrm{H}_{2} \mathrm{O}$ and $\mathrm{FeCl}_{3}$ in $100 \mathrm{~mL}$ of distilled water, respectively.

\subsection{The Synthesis of Iron-Alginate Gel Beads}

Iron-alginate gel beads were synthesized by the method previously reported by Rosales et al., 2012 [10]. According to that, $100 \mathrm{~mL}$ of sodium alginate solution $2.0 \%(\mathrm{w} / \mathrm{v})$ was dropped into $200 \mathrm{~mL}$ of the solution composed of $0.15 \mathrm{M}$ $\mathrm{Ba}^{2+}$ and $0.05 \mathrm{M} \mathrm{Fe}^{3+}$ in 1:1 volume ratio by a syringe pump at a flow rate of $5 \mathrm{~mL} / \mathrm{min}$ into for the gel bead formation.
The spherical iron-alginate gel beads (Fe-Alg gel beads) formed by the contact of the alginate including $\mathrm{Fe}^{3+}$ and $\mathrm{Ba}^{2+}$; after that, the solution containing beads was stirred magnetically at a low velocity and $25^{\circ} \mathrm{C}$ temperature for $2 \mathrm{~h}$ for the stabilization of beads. The formed brown particles (Fig. 2) were treated at $+4{ }^{\circ} \mathrm{C}$ for $2 \mathrm{~h}$ in the gelling solution. Thereafter, they were simply decanted and washed with distilled water. Finally, the beads were dried in an oven at $70{ }^{\circ} \mathrm{C}$ for $4 \mathrm{~h}$.

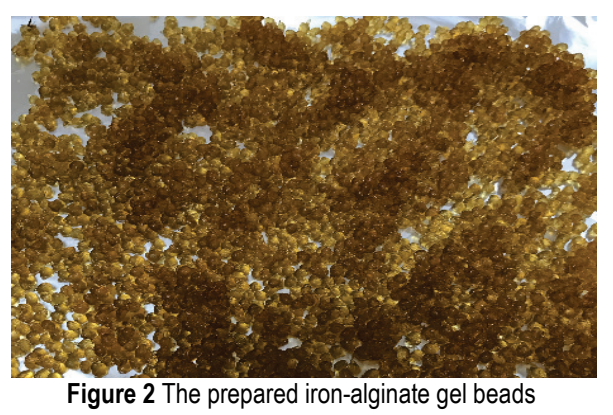

\subsection{Characterization Studies}

The morphology and elemental identification of beads were analyzed by the Scanning Electron Microscope (SEM) analysis, and Energy Dispersive X-ray Analysis (EDX), respectively before and after decolorization experiments. The functional groups of synthesized Fe-Alg gel beads were determined by the Fourier Transform Infrared Spectrometer (FT-IR) in the range of $4000-400 \mathrm{~cm}^{-1}$, preand post- decolorization.

\subsection{Heterogeneous Fenton-Like Decolorization Experiments}

Heterogeneous Fenton-like decolorization experiments of PR MX-5B were carried out on $100 \mathrm{~mL}$ of dye solutions in a water bath at a constant shaking rate and constant temperature $\left(25^{\circ} \mathrm{C}\right)$. In decolorization experiments, the required amount of Fe-Alg gel beads was added to the dye solution which was adjusted to the desired initial concentration and initial $\mathrm{pH}$ value. Then, $5.0 \mathrm{~mL}$ of $\mathrm{H}_{2} \mathrm{O}_{2}$ solution at different concentrations were added rapidly to the PR MX-5B dye solution and the Fenton-like decolorization began. The Erlenmeyer flasks $(250 \mathrm{~mL})$ were agitated water baths for the required reaction times. Then, samples were taken at pre-determined time intervals. Afterward, the UVvis absorbance readings were carried out on samples by a spectrophotometer (Specord 210 Plus, Analytic Jena, Germany).

The decolorization percentage for PR MX-5B was reduced in UV-vis absorbance and determined by Eq. (3) as follows:

$$
D=\frac{\left.A_{\mathrm{o}}\right|_{538 \mathrm{~nm}}-\left.A_{\mathrm{t}}\right|_{538 \mathrm{~nm}}}{\left.A_{\mathrm{o}}\right|_{538 \mathrm{~nm}}} \times 100 \%
$$

Where $D(\%)$ represents decolorization efficiency, $A_{\mathrm{o}}$ and $A_{\mathrm{t}}$ are the absorbance values at an initial time and at any time of 
PR MX-5B. Moreover, the control tests without an added catalyst were done to detect the decolorization capacity of $\mathrm{H}_{2} \mathrm{O}_{2}$ for PR MX-5B.

Experiments were carried out to examine the effects of other Fenton-like reaction parameters on dye decolorization as $\mathrm{pH}(3-6)$, initial dye concentration $(100-500 \mathrm{mg} / \mathrm{L})$, Fe-Alg gel beads (catalyst) concentration $(0.5-5 \mathrm{~g} / \mathrm{L})$ and $\mathrm{H}_{2} \mathrm{O}_{2}$ concentration.

\section{RESULTS AND DISCUSSION}

\subsection{The Characterization of Iron-Alginate Gel Beads}

The morphology and elemental analysis of the synthesized gel beads were investigated by SEM and EDX analysis, respectively, before and after decolorization. The SEM images are shown in Fig. 3 (a, b, c, d). As seen in Fig. $3 a$, the beads have a spherical shape and the SEM image (Fig. $3 d$ ), after the Fenton-like reaction showed that the surface change may be due to breakage of alginate chains and iron ions came out from the inner surface of beads. Furthermore, the average particle size of dried iron-alginate gel beads was calculated to be $231 \mu \mathrm{m}$ by using the Image $\mathrm{J}$ program with SEM images.
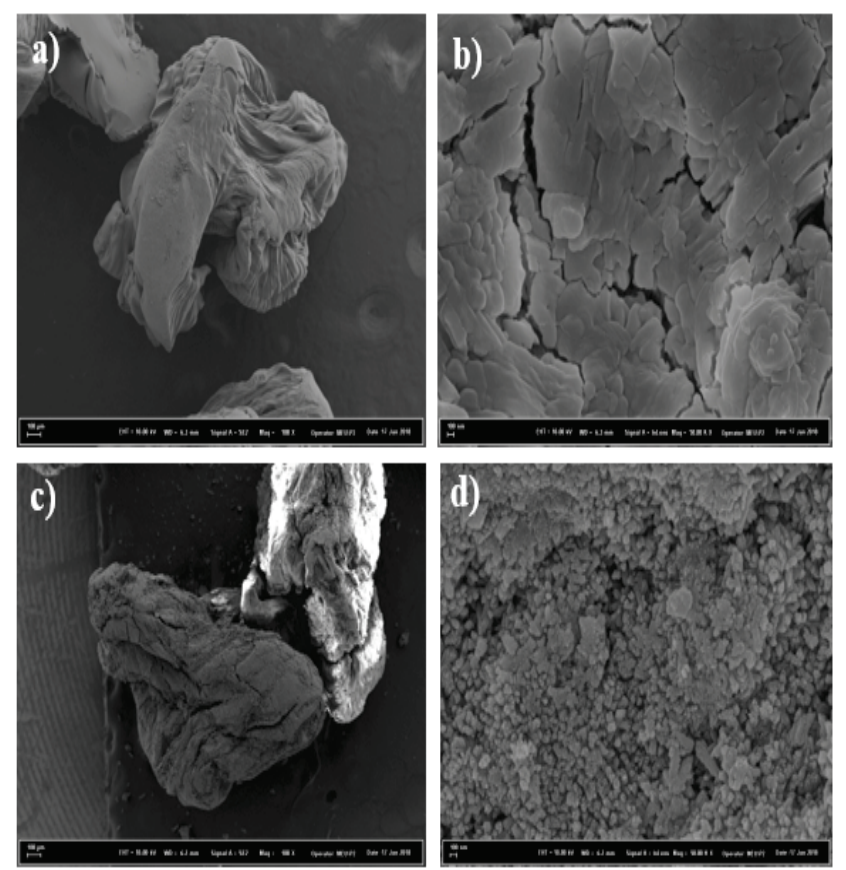

Figure 3 SEM images of iron-alginate gel beads before reaction: a) $100 \mathrm{KX}, \mathrm{b}$ ) $50.00 \mathrm{KX}$; iron-alginate gel beads after reaction: c) $100 \mathrm{KX}$, d) $50.00 \mathrm{KX}$

The EDX spectrums and the elemental and quantitative weight composition (wt. \%) of Fe-Alg gel beads before and after the reaction were presented in Fig. $4(a, b)$ and Tab.1, respectively. The cross-link between $\mathrm{Fe}$ and alginate leads to obtaining brown beads according to alginate beads without Fe. It is reported that ionic cross-links occur when alginate gets in touch with $\mathrm{Ca}^{2+}$ and $\mathrm{Ba}^{2+}$ to create an "egg-box" structure.

Hence, when alginate droplets are immersed into a ferrous aqueous solution, ionic cross-links could be constructed among the carboxyl group on alginate chains and iron [10].

According to the EDX results, the prepared Fe-Alg gel beads involve the elements of $\mathrm{Fe}, \mathrm{Ba}, \mathrm{C}, \mathrm{O}, \mathrm{Cl}, \mathrm{Pt}, \mathrm{Pd}, \mathrm{Na}, \mathrm{N}$, $\mathrm{S}$, and $\mathrm{Al}$ (the peaks of the elements of $\mathrm{Pt}$ and $\mathrm{Pd}$ stem from the coating of the sample) before reaction. As a consequence, the formation of Fe-Alg gel beads was approved by the signals in the $\mathrm{Fe}$ and $\mathrm{Ba}$ regions. Furthermore, the elements of $\mathrm{C}, \mathrm{O}$, and $\mathrm{Na}$ stem from the alginate structure $\left(\mathrm{C}_{6} \mathrm{H}_{7} \mathrm{NaO}_{6}\right)$ n. From the EDX spectrum, after the reaction, Fe, Ba, C, O, $\mathrm{Cl}, \mathrm{Pt}, \mathrm{Pd}, \mathrm{Na}, \mathrm{N}$, and $\mathrm{S}$ elements were detected in the structure.

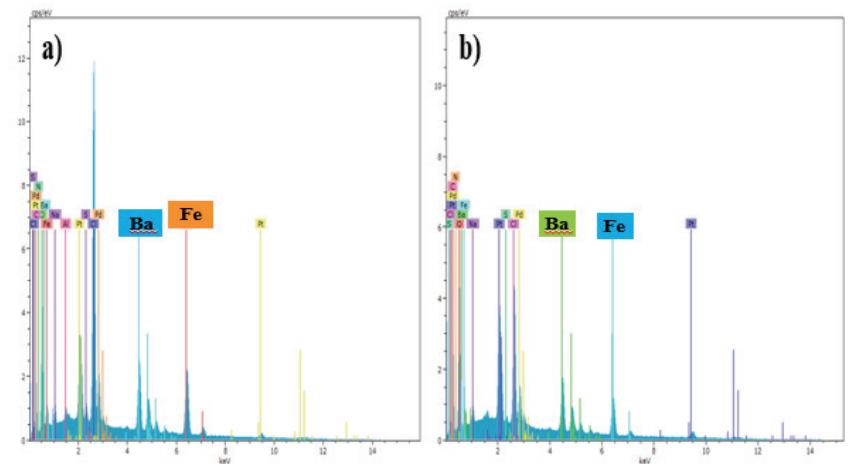

Figure 4 EDX spectrums of Fe-Alg gel beads a) before b) after the reaction

Table 1 Elemental composition of Fe-Alg gel beads before and after the Fentonlike degradation

\begin{tabular}{|c|c|c|}
\hline \multirow{2}{*}{ Element } & \multicolumn{2}{|c|}{ Weight (\%) } \\
\cline { 2 - 3 } & $\begin{array}{c}\text { Synthesized } \\
\text { Fe-Alg gel beads }\end{array}$ & $\begin{array}{c}\text { After the Fenton-like } \\
\text { reaction }\end{array}$ \\
\hline $\mathrm{Ba}$ & 24.65 & 26.07 \\
\hline $\mathrm{Fe}$ & 24.44 & 17.99 \\
\hline $\mathrm{C}$ & 6.45 & 16.80 \\
\hline $\mathrm{O}$ & 17.79 & 24.90 \\
\hline $\mathrm{Cl}$ & 22.50 & 11.97 \\
\hline $\mathrm{Na}$ & 1.678 & 1.523 \\
\hline $\mathrm{N}$ & 1.115 & 1.421 \\
\hline $\mathrm{S}$ & 0.716 & 0.076 \\
\hline $\mathrm{Al}$ & 0.657 & - \\
\hline
\end{tabular}

The FT-IR spectra of Fe-Alg gel beads before and after decolorization were presented in Fig. 5 (a, b). In Fig. 5.a, the broad peak at around $3300 \mathrm{~cm}^{-1}$ is ascribed to the hydrogenbonded $\mathrm{O}-\mathrm{H}$ stretching, and $2362 \mathrm{~cm}^{-1}$ is due to the $\mathrm{C} \equiv \mathrm{C}$ stretching vibration $[10,12]$. The band at $1028 \mathrm{~cm}^{-1}$ is attributed to the $\mathrm{C}-\mathrm{O}-\mathrm{C}$ stretching due to the saccharide structure of sodium alginate [13]. The band at $1406 \mathrm{~cm}^{-1}$ is contributed to the $\mathrm{C}-\mathrm{OH}$ deformation vibration with the contribution of the $\mathrm{O}-\mathrm{C}-\mathrm{O}$ symmetric stretching vibration of the carboxylate group. $1596.6 \mathrm{~cm}^{-1}$ is assigned to the asymmetric stretching vibrations of the carboxyl group of the alginate molecule. The peak at $1726 \mathrm{~cm}^{-1}$ in the spectrum of the Fe-Alg gel bead also belongs to the absorption vibrations of the carboxyl group of the alginate molecule [10,13].

Moreover, as seen from Fig. 5, a decrease was observed in the FT-IR peaks' intensity in the part before and after degradation. This situation may result from the change in the distance of the $\mathrm{C}-\mathrm{O}$ bond of the carboxylate group due to the bonding strength between the iron ion and the oxygen of the 
carboxyl group changes [10]. As seen from Fig. 5, b, the peak at $1726 \mathrm{~cm}^{-1}$ disappeared after decolorization. This result could be due to a decrease in the absorption vibrations of the carboxyl group of the alginate molecule.

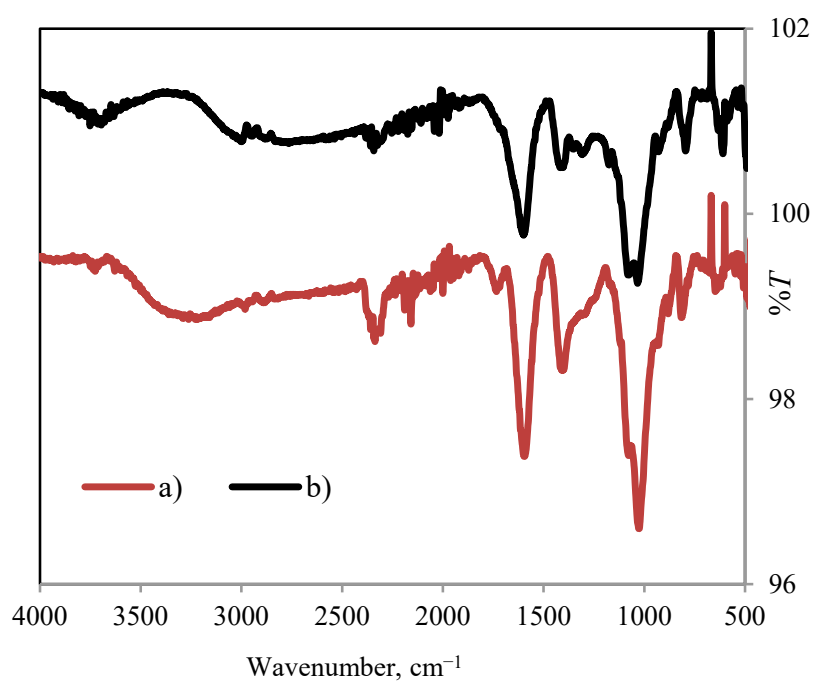

Figure 5 FT-IR spectra of Fe-Alg gel beads a) before b) after the Fenton-like reaction

\subsection{The Analysis of Dye Decolorization}

The catalytic efficiency of the synthesized Fe-Alg gel beads was assessed in the heterogeneous Fenton-like decolorization of PR MX-5B.

The Fenton degradation mechanism depends on the production of reactive hydroxyl radicals $(\mathrm{OH} \bullet)$ by the decomposition of $\mathrm{H}_{2} \mathrm{O}_{2}$ in the presence of $\mathrm{Fe}^{2+}$ ions. In the classical Fenton system, the formation cycles of hydroxyl radicals were given in Eqs. (4) - (10); [14].

$$
\begin{aligned}
& \mathrm{Fe}^{2+}+\mathrm{H}_{2} \mathrm{O}_{2} \rightarrow \mathrm{OH} \bullet+\mathrm{OH}^{-}+\mathrm{Fe}^{3+} \\
& \mathrm{Fe}^{3+}+\mathrm{H}_{2} \mathrm{O}_{2} \rightarrow \mathrm{Fe}^{2+}+\mathrm{H}^{+}+\mathrm{HO}_{2} \bullet \\
& \mathrm{Fe}^{3+}+\mathrm{HO}_{2} \bullet \rightarrow \mathrm{Fe}^{2+}+\mathrm{H}^{+}+\mathrm{O}_{2} \\
& \mathrm{Fe}^{2+}+\mathrm{OH}^{\bullet} \rightarrow \mathrm{Fe}^{3+}+\mathrm{OH}^{-} \\
& \mathrm{OH} \bullet+\mathrm{OH} \bullet \rightarrow \mathrm{H}_{2} \mathrm{O}_{2} \\
& \mathrm{OH} \bullet+\mathrm{H}_{2} \mathrm{O}_{2} \rightarrow \mathrm{H}_{2} \mathrm{O}+\mathrm{HO}_{2} \bullet \\
& \mathrm{OH} \bullet+\text { organic molecules } \rightarrow \mathrm{CO}_{2}+\mathrm{H}_{2} \mathrm{O}
\end{aligned}
$$

According to Eqs. (4) - (10), firstly, ferrous ions begin the Fenton-like oxidation and cause the formation of hydroxyl radicals, and afterward, these form hydroxyl radicals and assault the organic contaminants and lead to their disruption to smaller organic compounds [14].

The progress of the Fenton-like decolorization of the PR MX-5B dye was observed by the UV-vis spectral analysis. The variations in the spectrum over time were presented in Fig. 6.

Moreover, the changes in the color of dyestuff solution overtime were given in the inset of Fig. 6. PR MX-5B has the absorption peaks at $510.97 \mathrm{~nm}$ and $538.04 \mathrm{~nm}$, which are induced by the $\pi \rightarrow \pi^{*}$ electronic transition in a conjugated system linked by azo groups [15].
As seen in Fig. 6, adsorption peaks progressively declined and almost disappeared with the increase of reaction time. Furthermore, no new peaks that formed during the reaction were determined.

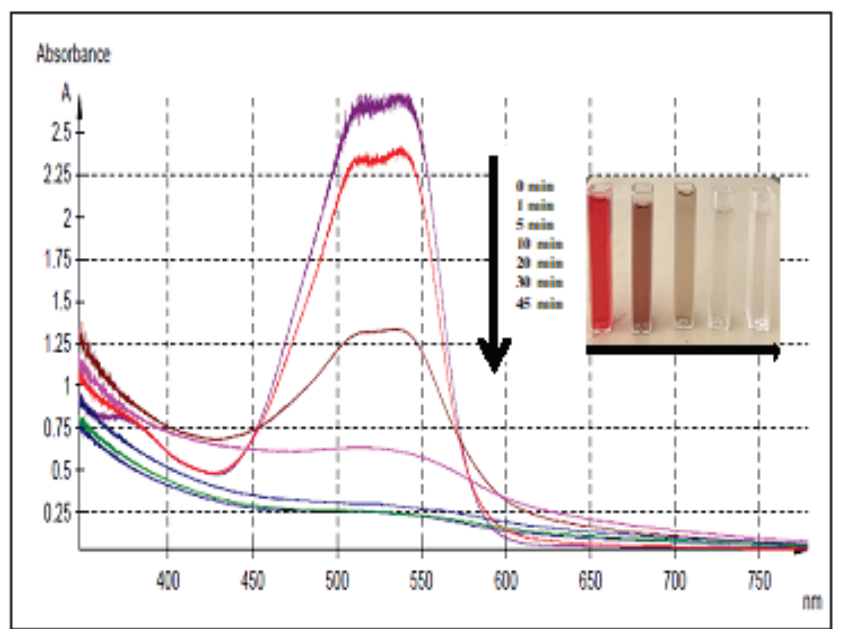

Figure 6 The UV-vis spectra of the PR MX-5B dye after decolorization $\left(C_{0}=100\right.$ $\mathrm{mg} / \mathrm{L}, \mathrm{C}_{\mathrm{H}_{2} \mathrm{O}_{2}}=20 \mathrm{mM}, \mathrm{X}_{0}=1 \mathrm{~g} / \mathrm{L}, \mathrm{pH}=3.0, T=298 \mathrm{~K}$ )

Consequently, the chromophoric group ( $\mathrm{N}=\mathrm{N}$ group), as well as the conjugated system in the PR MX-5B molecular structure, was broken and finally, the PR MX-5B molecule was decolorized.

\subsection{Effects of Parameters on the Decolorization of Procion Red MX-5B}

\subsubsection{Effect of the hydrogen peroxide concentration}

$\mathrm{H}_{2} \mathrm{O}_{2}$ concentration is a fundamental parameter to be determined in the heterogeneous Fenton-like reactions because of number of $\mathrm{OH} \cdot$ radicals which will initiate the reaction, depends directly on $\mathrm{H}_{2} \mathrm{O}_{2}$ concentration. At low concentrations of $\mathrm{H}_{2} \mathrm{O}_{2}$, not enough hydroxyl radicals can be obtained for efficient degradation, which is why the degradation rate could be long-term. Moreover, the best part of free radicals is immediately used up by the dye. Conversely, more $\mathrm{OH} \bullet$ radicals could be produced in the presence of a high concentration of $\mathrm{H}_{2} \mathrm{O}_{2}$, but these formed $\mathrm{OH} \cdot$ radicals preferably react with the excess of $\mathrm{H}_{2} \mathrm{O}_{2}$ [1].

The effect of the $\mathrm{H}_{2} \mathrm{O}_{2}$ concentration was presented in Fig. 7, at the experimental conditions of initial dye concentration: $100 \mathrm{mg} / \mathrm{L}$; natural $\mathrm{pH}$ of the solution (nearly 5.2), catalyst concentration $1 \mathrm{~g} / \mathrm{L}$, and temperature $298 \mathrm{~K}$.

As seen from Fig. 7, quite close $(\approx 98 \%)$ decolorization percentages were acquired when the $\mathrm{H}_{2} \mathrm{O}_{2}$ concentrations were $20 \mathrm{mM}, 30 \mathrm{mM}$, and $50 \mathrm{mM}$. Hence, the optimum $\mathrm{H}_{2} \mathrm{O}_{2}$ concentration was selected as $20 \mathrm{mM}$ in order to prevent unprofitable consumption of $\mathrm{H}_{2} \mathrm{O}_{2}$. Consequently, the $5 \mathrm{~mL}$ of $20 \mathrm{mM} \mathrm{H}_{2} \mathrm{O}_{2}$ was used in investigating the effect of other parameters. 


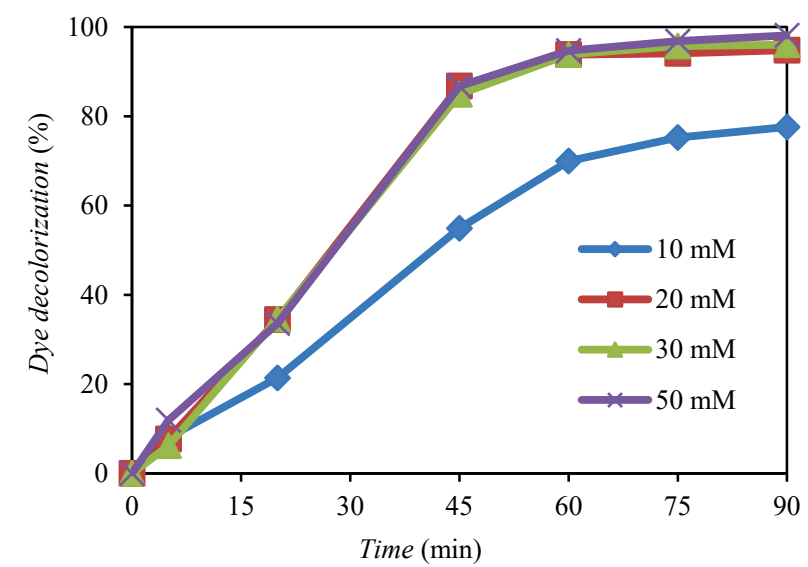

Figure 7 Effect of the $\mathrm{H}_{2} \mathrm{O}_{2}$ concentration on decolorization $\left(\mathrm{C}_{0}=100 \mathrm{mg} / \mathrm{L}, X_{0}=1\right.$ $\mathrm{g} / \mathrm{L}, \mathrm{pH}=$ natural $\mathrm{pH}(\approx 5.2)$ of dye solution, $T=298 \mathrm{~K})$

\subsubsection{Effect of the Initial pH}

One of the desired aims of heterogeneous Fenton-like reactions is developing new heterogeneous catalysts to extend the $\mathrm{pH}$ range. The $\mathrm{pH}$ is a decisive parameter which influences the efficiency of the Fenton-like process since $\mathrm{pH}$ has an important impact on the stability of $\mathrm{H}_{2} \mathrm{O}_{2}$, in controlling the catalytic activity, and the dominant iron species [16].

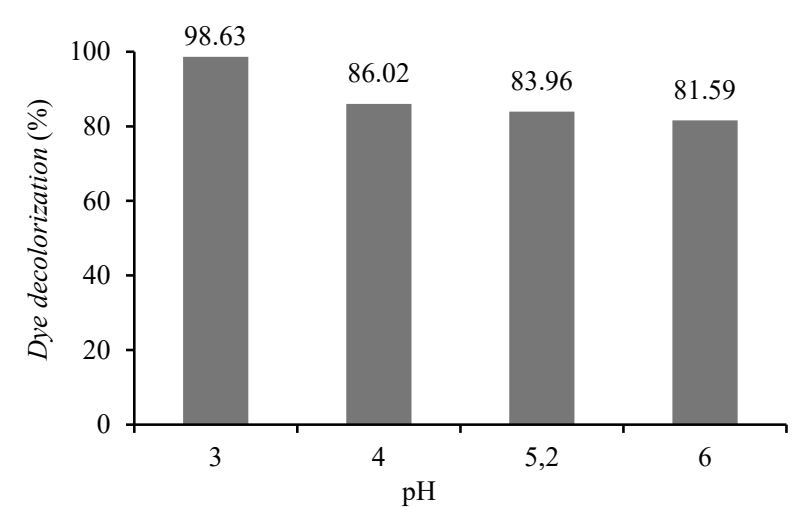

Figure 8 Effect of initial pH on decolorization $\left(C_{0}=100 \mathrm{mg} / \mathrm{L}, X_{0}=1 \mathrm{~g} / \mathrm{L}, \mathrm{C}_{\mathrm{H}_{2} \mathrm{O}_{2}}=5\right.$ $\mathrm{mL}$ of $20 \mathrm{mM}, T=298 \mathrm{~K}, t=45 \mathrm{~min}$ )

The effect of the initial $\mathrm{pH}$ of the solution on the catalytic Fenton like decolorization of PR MX-5B was researched at the $\mathrm{pH}$ values of $3.0,4.0$, natural $\mathrm{pH}(\approx 5.2)$, and 6.0. As seen from Fig. 8, the highest decolorization percentage (98.63\%) was obtained at $\mathrm{pH}$ 3.0. Moreover, remarkably higher and close decolorization yields (nearly $86 \%, 84 \%$, and $82 \%$ ) were achieved at the $\mathrm{pH}$ values of 4.0, 5.2, and 6.0, respectively. It was reported in the literature that the reaction between ironcontaining minerals and $\mathrm{H}_{2} \mathrm{O}_{2}$ could sufficiently degrade the organic molecules at higher $\mathrm{pH}$ values than at acidic $\mathrm{pHs}$ [17]. Furthermore, the formation of $\mathrm{Fe}(\mathrm{OH})_{3}$ can be prevented due to the ionic cross-links between the $\mathrm{Fe}$ ions and the carboxyl group on alginate chains. Therefore, working at natural $\mathrm{pH}$ values of dyestuff could avoid the formation of iron sludge at higher $\mathrm{pH}$ values.

These outcomes showed that the Fe-Alg gel beads $/ \mathrm{H}_{2} \mathrm{O}_{2}$ catalytic system could effectively continue in the catalytic degradation of RR MX-5B at the $\mathrm{pH}$ range of 3 and 6 , indicating the apparent improvement in $\mathrm{pH}$-tolerance.

\subsubsection{Effect of Catalyst Concentration}

The effect of catalyst concentration on the PR MX-5B decolorization was presented in Fig. 9.

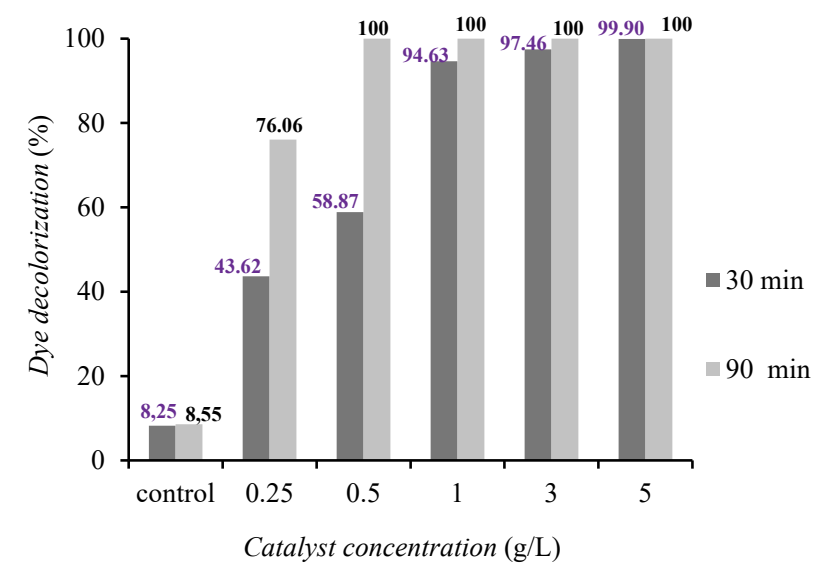

Figure 9 Effect of Fe-Alg gel beads concentration on decolorization $\left(C_{0}=100\right.$ $\mathrm{mg} / \mathrm{L}, \mathrm{C}_{\mathrm{H}_{2} \mathrm{O}_{2}}=5 \mathrm{~mL}$ of $20 \mathrm{mM}, \mathrm{pH}=3.0, T=298 \mathrm{~K}$, control represents the dye solution without an added catalyst)

Five different catalyst concentrations, from $0.25 \mathrm{~g} / \mathrm{L}$ to $5.0 \mathrm{~g} /$, were selected to determine dye decolorization efficiencies. Besides that, a control experiment was carried out without an added catalyst by using the dye solution containing only the $\mathrm{H}_{2} \mathrm{O}_{2}$. As seen in Fig. 9, the control (free catalyst concentration) showed nearly $8.25 \%$ PR MX-5B dye decolorization efficiency, and decolorization percentages were increased with an increment in catalyst concentration from $0.25 \mathrm{~g} / \mathrm{L}$ to $5 \mathrm{~g} / \mathrm{L}$. This result arises from the increment in the number of active sites of Fe-Alg gel beads. Therefore, $\mathrm{H}_{2} \mathrm{O}_{2}$ decomposition improves and leads to the formation of more $\mathrm{OH} \bullet$ radicals.

Moreover, when the Fe-Alg gel beads' concentrations were $0.5,1.0,3.0$, and $5.0 \mathrm{~g} / \mathrm{L}, \approx 100 \%$ dye decolorization percentages were obtained for $100 \mathrm{mg} / \mathrm{L}$ PR MX-5B concentrations at the end of the $90 \mathrm{~min}$ reaction time. Moreover, when catalyst concentration increased, the reaction time needed to obtain the $100 \%$ decolorization yield decreased. Hence, the $5 \mathrm{~g} / \mathrm{L}$ of catalyst concentration was chosen as the optimum one to achieve the decolorization removal of high concentrations of dye solutions in a short time.

\subsubsection{Effect of Initial Dye Concentration}

The effect of initial contaminant concentration on decolorization was shown in Fig. 10. In this study, nearly $100 \%, 100 \%$, and $96 \%, 77 \%, 76 \%$, and $71 \%$ decolorization yields were achieved for the initial dye concentrations from $50 \mathrm{mg} / \mathrm{L}$ to $500 \mathrm{mg} / \mathrm{L}$, at the end of the $180 \mathrm{~min}$ reaction time. Namely, all of the dyestuffs were decolorized in low 
concentrations of PR MX-5B, but lower decolorization yields were obtained in high initial dye concentrations.

This phenomenon may be due to the concentration of PR MX-5B affecting the generation of $\mathrm{OH} \bullet$ radicals and their scavengers. Less scavenging of hydroxyl radicals is formed when the initial organic pollutant concentration was increased without an overlap in its optimum value [7].

Therefore, initial dye concentrations of $50 \mathrm{mg} / \mathrm{L}, 100$ $\mathrm{mg} / \mathrm{L}$, and $200 \mathrm{mg} / \mathrm{L}$ were selected as suitable for the optimal period needed for the reaction which will prevent the acceleration of the formation of radical $\mathrm{OH} \bullet$ scavengers.

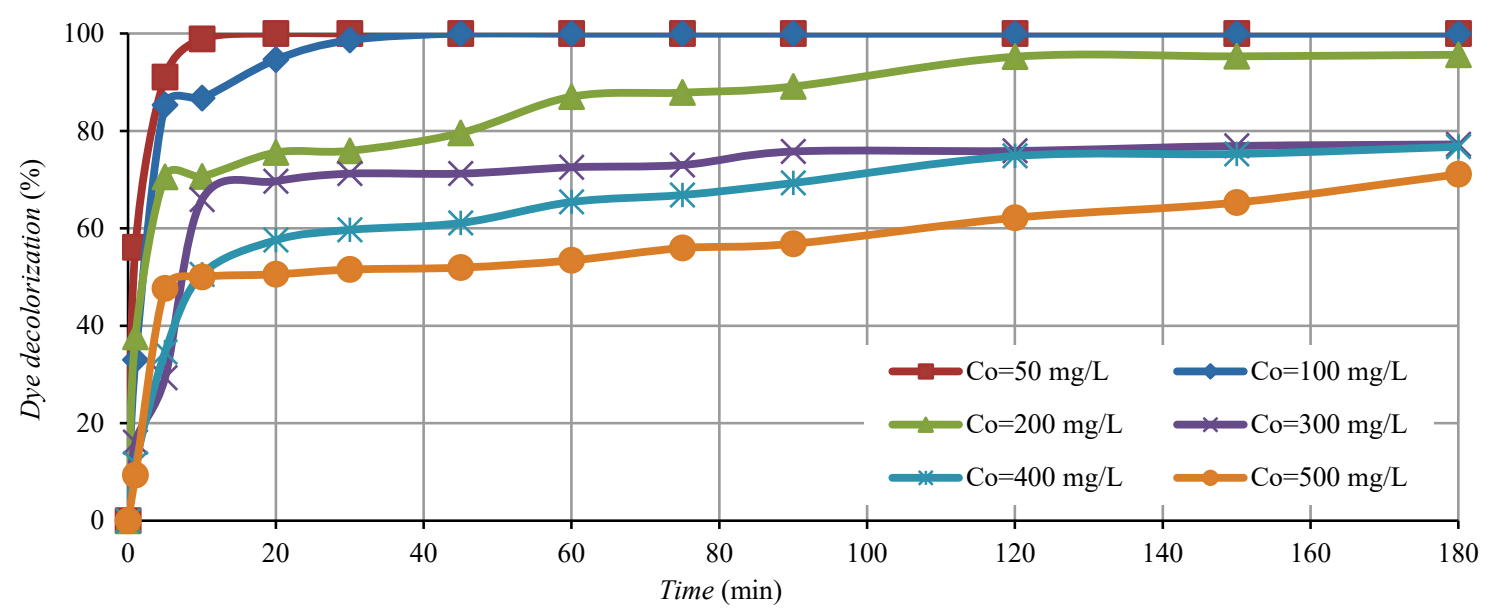

Figure 10 Effect of the initial dye concentration on decolorization $\left(X_{0}=5 \mathrm{~g} / \mathrm{L}, \mathrm{C}_{2} \mathrm{O}_{2}=5 \mathrm{~mL}\right.$ of $\left.20 \mathrm{mM}, \mathrm{pH}=3.0, T=298 \mathrm{~K}\right)$

Moreover, many studies were carried out in literature for the removal of PR MX-5B by Fenton processes. Some examples of these studies were presented in Tab. 2. In this study, comparing the studies given in Tab. 2, high PR MX5B decolorization efficiencies were obtained in the studied range of initial dye concentrations. Therefore, the obtained results showed that effective removal efficiencies can be achieved for wastewaters including high concentrations of PR MX-5B in a single step by using Fe-Alg gel beads as a heterogeneous Fenton-like catalyst.

Table 2 Some of the examples on the studies for the removal of PR MX-5B from the literature

\begin{tabular}{|c|c|c|c|c|c|}
\hline Catalyst & Method & $C_{[\mathrm{PR} M X-5 \mathrm{~B}]}$ & $D(\%)$ & $t(\min )$ & Ref. \\
\hline Ferric sulfate & Fenton-like decolorization & $40 \mathrm{ppm}$ & 100 & 60 & [18] \\
\hline $\mathrm{TiO}_{2}$ & Photocatalytic oxidation & $40 \mathrm{ppm}$ & 100 & 20 & [19] \\
\hline $\begin{array}{l}\text { Iron(III) Nitrate Nonahydrate and Iron(II) } \\
\text { Sulfate Heptahydrate }\end{array}$ & Fenton $\left(\mathrm{H}_{2} \mathrm{O}_{2} / \mathrm{Fe}^{2+}\right)$ and Fenton-like degradation $\left(\mathrm{H}_{2} \mathrm{O}_{2} / \mathrm{Fe}^{3+}\right)$ & $0.1 \mathrm{mM}$ & $>99$ & 480 & [20] \\
\hline $\mathrm{Fe} /$ Walnut shell based Activated carbon & Photo Fenton-like process & $100 \mathrm{ppm}$ & 88.3 & 120 & [21] \\
\hline $\mathrm{Fe} / \mathrm{K}$-Activated carbon & Fenton-like process & $100 \mathrm{ppm}$ & 91.6 & 120 & [22] \\
\hline Fe-Alg gel beads & Fenton-like decolorization & $50-500 \mathrm{ppm}$ & $100-71$ & 180 & This study \\
\hline
\end{tabular}

\subsection{Kinetic Study}

Zero, first and second order reaction kinetics were used in order to determine the kinetics of the Fenton-like decolorization of PR MX-5B. The zero, first, and second order rate equations are written as below (Eqs. (11) (13)) [23]:

$0^{\text {th }}$ order reaction kinetics: $\frac{\mathrm{d} C}{\mathrm{~d} t}=-k_{0}$

$1^{\text {st }}$ order reaction kinetics: $\frac{\mathrm{d} C}{\mathrm{~d} t}=-k_{1} C$

$2^{\text {nd }}$ order reaction kinetics: $\frac{\mathrm{d} C}{\mathrm{~d} t}=-k_{2} C^{2}$

Where: $C$ is the concentration of the dye solution; $k_{0}, k_{1}, k_{2}$ apparent kinetic rate constants of zero, first, and second order reaction kinetics, respectively; $t$ is the reaction time.
When integrating the Eqs. (10) - (13), the following equations are obtained (Eqs. (14) - (16)):

$$
\begin{aligned}
C_{t} & =C_{0}-k_{0} t \\
C_{t} & =C_{0} e^{-k_{1} t} \\
\frac{1}{C_{t}} & =\frac{1}{C_{0}}+k_{2} t
\end{aligned}
$$

Where $C_{t}$ is the concentration of PR MX-5B at any reaction in the time $t$.

The reaction kinetics for the decolorization with the regression coefficients was calculated. According to the results, the decolorization kinetics of PR MX-5B fitted the $2^{\text {nd }}$ order kinetics well when comparing the regression coefficients $\left(R^{2}\right)$ which were determined from the reaction kinetics. The regression value of the $2^{\text {nd }}$ order reaction kinetics was 0.995 , which was much higher than the $0^{\text {th }}$ order $\left(R^{2}=0.4611\right)$ and the $1^{\text {st }}$ order reaction kinetics $\left(R^{2}=0.5631\right)$, 
(data not shown). The second order reaction kinetics for the decolorization of PR MX-5B was presented in Fig. 11 for this study.

Therefore, the decolorization of PR MX-5B best fitted the second order reaction kinetics of the type:

$-r_{[\mathrm{PR} M X-5 \mathrm{~B}]} \approx k_{2} C_{\mathrm{PR} \mathrm{MX}-5 \mathrm{~B}}^{2}$

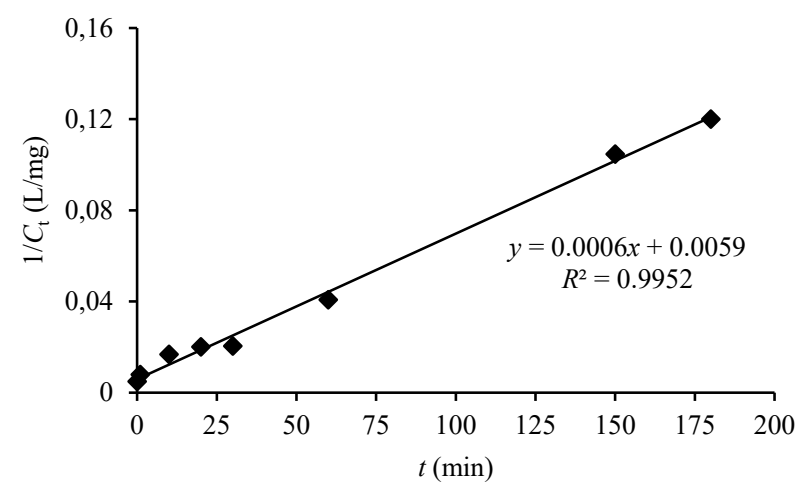

Figure 11 The $2^{\text {nd }}$ order reaction kinetics for the decolorization of PR MX-5B. Experimental conditions: $\mathrm{C}_{0}=200 \mathrm{mg} / \mathrm{L} ; \mathrm{C}_{\mathrm{H}_{2} \mathrm{O}_{2}}=5 \mathrm{~mL}$ of $20 \mathrm{mM}, \mathrm{pH}=3.0, X_{0}=$ $5 \mathrm{~g} / \mathrm{L}, \mathrm{T}=298 \mathrm{~K}, t=180 \mathrm{~min}$

As seen from Fig. 11, the apparent kinetic rate constant, $k_{2}$ was determined to be $0.0006 \mathrm{~L} / \mathrm{mg}$.min at the reaction conditions of PR MX-5B concentration: $200 \mathrm{mg} / \mathrm{L} ; \mathrm{H}_{2} \mathrm{O}_{2}$ concentration: $20 \mathrm{mM}$; initial $\mathrm{pH}$ of solution: 3.0 ; catalyst concentration: $5 \mathrm{~g} / \mathrm{L}$; temperature $298 \mathrm{~K}$ and $180 \mathrm{~min}$ reaction time.

\section{CONCLUSION}

In the presented study, iron-alginate gel beads were synthesized and their utilization was investigated as a heterogeneous Fenton-like catalyst for the decolorization of an azo dye, PR MX-5B. The breakdown of the azo band in the chromophore of the dye with $\mathrm{OH} \cdot$ radicals was demonstrated by the UV-vis by spectral analysis, and the reaction time due to the absorption peaks declined as time passed and finally disappeared.

The Fenton-like degradation was fairly efficient, and high dye decolorization percentages from $100 \%$ to $71 \%$ were obtained in the range of $50-500 \mathrm{mg} / \mathrm{L}$ dye concentrations, at the end of the $180 \mathrm{~min}$ reaction time. Furthermore, the kinetic study demonstrated that the reaction kinetics of PR MX-5B fitted the second order kinetics well.

Moreover, high decolorization percentages were obtained in the range of the initial $\mathrm{pH}$ of 3.0-6.0, showing the $\mathrm{pH}$ tolerance of the system. The results indicated that Fe-alginate gel beads could be used as a catalyst effectively in the heterogeneous Fenton-like reactions for the removal of azo dyestuffs. The using of Fe-Alg gel beads offers several advantages owing to their ease of production, high capability of decomposing the hydrogen peroxide and formation the $\mathrm{OH} \bullet$ radicals to provide effective decolorization. In addition, they can be easily separated from the reaction medium after the procedure and overcome the formation of iron sludge by classical Fenton decomposition Fenton's degradation, especially at higher $\mathrm{pH}$ values than at acidic values.

\section{REFERENCES}

[1] Kasiri, M. B., Aleboyeh, H., \& Aleboyeh, A. (2008). Degradation of Acid Blue 74 using Fe-ZSM5 zeolite as a heterogeneous photo-Fenton catalyst. Applied Catalysis B: Environmental, 84(1-2), 9-15. https://doi.org/10.1016/j.apcatb.2008.02.024

[2] Pokharia, A. \& Ahluwalia, S. S. (2016). Biodecolorization and degradation of xenobiotic azo dye-Basic Red 46 by Staphylococcus epidermidis MTCC 10623. Int. J. Res. Biosciences, 5(2), 10-23.

[3] Nidheesh, P. V., Gandhimathi, R., \& Ramesh, S. T. (2013). Degradation of dyes from aqueous solution by Fenton processes: a review. Environmental Science and Pollution Research, 20(4), 2099-2132. https://doi.org/10.1007/s11356-012-1385-z

[4] Guivarch, E., Trevin, S., Lahitte, C., \& Oturan, M. A. (2003). Degradation of azo dyes in water by electro-Fenton process. Environmental Chemistry Letters, 1(1), 38-44. https://doi.org/10.1007/s10311-002-0017-0

[5] Wang, N., Zheng, T., Zhang, G., \& Wang, P. (2016). A review on Fenton-like processes for organic wastewater treatment. Journal of Environmental Chemical Engineering, 4(1), 762787. https://doi.org/10.1016/j.jece.2015.12.016

[6] Mazilu, I., Ciotonea, C., Chirieac, A., Dragoi, B., Catrinescu, C., Ungureanu, A., S. Petit, S. Royer, and Dumitriu, E. (2017). Synthesis of highly dispersed iron species within mesoporous (Al-) SBA-15 silica as efficient heterogeneous Fenton-type catalysts. Microporous and Mesoporous Materials, 241, 326337. https://doi.org/10.1016/j.micromeso.2016.12.024

[7] Li, R., Gao, Y., Jin, X., Chen, Z., Megharaj, M., \& Naidu, R. (2015). Fenton-like oxidation of 2, 4-DCP in aqueous solution using iron-based nanoparticles as the heterogeneous catalyst. Journal of colloid and interface science, 438, 87-93. https://doi.org/10.1016/j.jcis.2014.09.082

[8] Kuang, Y., Wang, Q., Chen, Z., Megharaj, M., \& Naidu, R. (2013). Heterogeneous Fenton-like oxidation of monochlorobenzene using green synthesis of iron nanoparticles. Journal of colloid and interface science, 410, 67-73. https://doi.org/10.1016/j.jcis.2013.08.020

[9] Ren, H., Gao, Z., Wu, D., Jiang, J., Sun, Y., \& Luo, C. (2016). Efficient $\mathrm{Pb}$ (II) removal using sodium alginatecarboxymethyl cellulose gel beads: preparation, characterization, and adsorption mechanism. Carbohydrate polymers, 137, 402-409. https://doi.org/10.1016/j.carbpol.2015.11.002

[10] Rosales, E., Iglesias, O., Pazos, M., \& Sanromán, M. A. (2012). Decolorization of dyes under electro-Fenton process using $\mathrm{Fe}$ alginate gel beads. Journal of hazardous materials, 213, 369377. https://doi.org/10.1016/j.jhazmat.2012.02.005

[11] Lin, Y. C. \& Lee, H. S. (2010). Effects of $\mathrm{TiO}_{2}$ coating dosage and operational parameters on $\mathrm{TiO}_{2} / \mathrm{Ag}$ photocatalysis system for decolorization Procion red MX-5B. Journal of hazardous materials, 179(1-3), 462-470. https://doi.org/10.1016/j.jhazmat.2010.03.026

[12] Kannan, A. \& Thambidurai, S. (2008). Removal of hexavalent chromium from aqueous solution using activated carbon derived from palmyra palm fruit seed. Bulletin of the Chemical Society of Ethiopia, 22(2). https://doi.org/10.4314/bcse.v22i2.61282

[13] Li, P., Dai, Y. N., Zhang, J. P., Wang, A. Q., \& Wei, Q. (2008). Chitosan-alginate nanoparticles as a novel drug delivery 
system for nifedipine. International journal of biomedical science: IJBS, 4(3), 221.

[14] Cihanoğlu, A., Gündüz, G., \& Dükkanc1, M. (2015). Degradation of acetic acid by heterogeneous Fenton-like oxidation over iron-containing ZSM-5 zeolites. Applied Catalysis B: Environmental, 165, 687-699. https://doi.org/10.1016/j.apcatb.2014.10.073

[15] Zhu, G., Yin, J., Wan, P., Zheng, H., \& Deng, B. (2015). Fe (III)/H2O2-Like System for Removal of Azo Dye from Aqueous Solution. Separation Science and Technology, 50(14), 2220-2229. https://doi.org/10.1080/01496395.2015.1020551

[16] Xu, L. \& Wang, J. (2011). A heterogeneous Fenton-like system with nanoparticulate zero-valent iron for removal of 4-chloro3-methyl phenol. Journal of hazardous materials, 186(1), 256264. https://doi.org/10.1016/j.jhazmat.2010.10.116

[17] Xue, X., Hanna, K., \& Deng, N. (2009). Fenton-like oxidation of Rhodamine B in the presence of two types of iron (II, III) oxide. Journal of hazardous materials, 166(1), 407-414. https://doi.org/10.1016/j.jhazmat.2008.11.089

[18] Wu, C. H. (2008). Decolorization of CI Reactive Red 2 in $\mathrm{O}_{3}$, Fenton-like and $\mathrm{O}_{3} /$ Fenton-like hybrid systems. Dyes and Pigments, 77(1), 24-30. https://doi.org/10.1016/j.dyepig.2007.03.002

[19] So, C. M., Cheng, M. Y., Yu, J. C., \& Wong, P. K. (2002). Degradation of azo dye Procion Red MX-5B by photocatalytic oxidation. Chemosphere, 46(6), 905-912. https://doi.org/10.1016/S0045-6535(01)00153-9

[20] Hsueh, C. L., Huang, Y. H., Wang, C. C., \& Chen, C. Y. (2005). Degradation of azo dyes using low iron concentration of Fenton and Fenton-like system. Chemosphere, 58(10), 1409-1414. https://doi.org/10.1016/j.chemosphere.2004.09.091

[21] Palas, B., Ersöz, G., \& Atalay, S. (2016). Heterogeneous photo Fenton-like oxidation of Procion Red MX-5B using walnut shell based green catalysts. Journal of Photochemistry and Photobiology A: Chemistry, 324, 165-174. https://doi.org/10.1016/j.jphotochem.2016.03.031

[22] Palas, B., Ersöz, G., \& Atalay, S. (2017). Green catalysts for Fenton-like oxidation of Procion Red MX-5B: Influence of the activation method and the reaction parameters on dye removal. Separation Science and Technology, 52(3), 404-420. https://doi.org/10.1080/01496395.2016.1252399

[23] Sun, S. P., Li, C. J., Sun, J. H., Shi, S. H., Fan, M. H., \& Zhou, Q. (2009). Decolorization of an azo dye Orange G in aqueous solution by Fenton oxidation process: Effect of system parameters and kinetic study. Journal of hazardous materials, 161(2-3), 1052-1057.

https://doi.org/10.1016/j.jhazmat.2008.04.080

\section{Authors' contacts:}

Memduha ERGÜT, PhD, Research Assistant

Corresponding author

Mersin University, Faculty of Engineering, Department of Chemical Engineering

Mersin University Çiftlikköy Campus F Block, 33343, Yenişehir/Mersin, Turkey

Tel./Fax, +90 (0324) 36100 01-17371 / +90 (0324) 3610032

E-mail: memduha.ergut@gmail.com

Ayla ÖZER, PhD, Professor

Mersin University, Faculty of Engineering, Department of Chemical Engineering

Mersin University Çiftlikköy Campus F Block, 33343, Yenişehir/Mersin, Turkey

Tel./Fax, +90 (0324) 36100 01-17370 / +90 (0324) 3610032

E-mail: ayozer4@gmail.com 